\title{
Peran IAHN-TP Palangka Raya Dalam Melestarikan Identitas Kultural Penganut Hindu Kaharingan Di Kalimantan Tengah
}

\author{
Nali Eka \\ Institut Agama Hindu Negeri Tampung Penyang Palangka Raya \\ nalieka@iahntp.ac.id
}

\begin{abstract}
Previous research on Kaharingan has written more about various rituals and the integration of Kaharingan with Hinduism. While this paper aims to describe the role of Hindu Universities which have the responsibility to build and improve the quality of Hindu human resourches who have global competence. But still not uprooted from its cultural roots, one way is by participating in caring for and preserving the teachings of local wisdom. Where this lokal wisdom also has profitable potential. This descriptive-qualitative research uses a phenomenological approach to cultural adaptatioan and receptioan theory. The result of the studi showed that the Hindu Institute of Tampung Penyang Palangka Raya state as the Hindu religios College in Kalimantan applies a global minded education pattern to answer the demans of globalization and Hindu educatioan based on local wisdom Kaharingan as identity or cultural identity. The application of this local wisdom based education in the form of local wisdom courses such as Tawur, Tandak, Acara Agama Hindu Kaharingan, Panaturan, Bahasa Sangiang, Bahasa Daerah, Teologi Hindu Kaharingan and other Kaharingan local wisdom courses. Universities have roles and responsibility to mentain local wisdom as the identity of a community, so that Hindu human resource are competitive in facing the challenges of globalization, but are still not uprooted from their cultural roots.
\end{abstract}

Keyword: IAHN-TP Palangka Raya; Cultural Identity; Hindu Kaharingan

\begin{abstract}
Abstrak
Penelitian tentang Kaharingan sebelumnya lebih banyak menulis tentang berbagai ritual dan integrasi Kaharingan dengan agama Hindu. Sedangkan Tulisan ini bertujuan untuk menggambarkan bagaimana peran perguruan tinggi Hindu yang memiliki tanggungjawab membangun dan meningkatkan kualitas sumber daya manusia Hindu yang memiliki kompetensi global namun tetap tidak tercabut dari akar budayanya. Salah satunya dengan turut serta merawat dan melestarikan ajaran local wisdom. Dimana local wisdom ini juga memiliki potensi yang menguntungkan. Penelitian desktiptif-kualitatif ini menggunakan pendekatan fenomenologi dan menggunakan teori Fenomenologi, Adaptasi Budaya dan teori Resepsi. Hasil penelitian menunjukkan bahwa Institut Agama Hindu Negeri Tampung Penyang (IAHN-TP) Palangka Raya sebagai satu-satunya perguruan tinggi keagamaan Hindu yang ada di Kalimantan menerapkan pola pendidikan berwawasan global untuk menjawab kebutuhan tuntutan globalisasi dan pendidikan Hindu berbasis local wisdom Kaharingan sebagai jati diri atau identitas kultural. Penerapan pendidikan berbasis local wisdom ini dalam bentuk mata kuliah kearipan lokal seperti mata kuliah Tawur, Tandak, Acara Agama Hindu Kaharingan, Panaturan, bahasa Sangiang, bahasa Daerah, Teologi Hindu Kaharingan, dan mata kuliah kearipan Kaharingan lainnya. Perguruan tinggi memiliki peran dan tanggungjawab untuk menjaga local wisdom sebagai jati diri sebuah komunitas. Sehingga SDM Hindu memiliki daya saing menghadapi tantangan globalisasi namun tetap tidak tercabut dari akar budayanya.
\end{abstract}

Kata Kunci: IAHN-TP Palangka Raya; Identitas Kultural; Hindu Kaharingan 


\section{Pendahuluan}

Agama sebagai sistem sebuah sistem kebudayaan dapat mengubah tatanan sebuah masyarakat menjadi lebih teratur. Agama menurut Geertz (1992) menjadi bagian dari suatu sistem kebudayaan yang mengalami perluasan dan menyebar sehingga kedudukannya dapat menciptakan suatu hubungan yang dapat membentuk keteraturan kebudayaan. Penganut Hindu etnis Dayak yang lebih dikenal dengan identitas Hindu Kaharingan, setelah integrasi kepercayaan Kaharingan dengan salah satu agama resmi negara yaitu agama Hindu pada tahun 1980 tidak imun terhadap globalisasi dan modernisasi. Globalisasi dan modernisasi yang cenderung menyamakan membawa pengaruh ke dalam kehidupan, termasuk sistem religi yang dimiliki. Penganut Hindu dari etnis Dayak Ngaju di Kota Palangka Raya dengan sistem religi aslinya mengalami perkembangan pada dan dari dirinya sendiri sehingga adaptasi pasti berlangsung. Dalam proses adaptasi tentunya terjadi perubahan. Pada proses perubahan ini strukturasi, destrukturasi dan restrukturasi terjadi terus menerus secara bergantian.

Adaptasi sistem religi masyarakat Dayak Ngaju di satu sisi dapat mengubah keaslian tradisi, tetapi di sisi lain juga dapat berperan sebagai penguat dalam menjaga keberlangsungan sistem religi tersebut. Walaupun beradaptasi dengan keadaan dan regulasi negara penganut Hindu etnis Dayak telah mampu mempertahankan identitas kulturalnya tanpa harus tercabut dari akarnya. Hal ini dapat terlihat dari praktek beragama yang dijalankan, walaupun secara resmi sebagai penganut agama Hindu, namun praktek beragama yang telah diwariskan leluhur kaharingan tetap dilaksanakan secara utuh. Kebertahanan identitas kultural penganut Hindu etnis Dayak ini tentunya tidak lepas dari kemampuan penganutnya untuk tetap merawat dan memelihara serta kemampuan lembaga terkait untuk turut serta menjaganya secara sistematis. Salah satu lembaga yang turut berperan dalam melestarikan dan merawat tradisi Kaharingan dan menjadi salah satu kampus satu-satunya yang ada di Kalimantan yaitu lembaga pendidikan keagamaan Hindu, Institut Agama Hindu Negeri Tampung Penyang (IAHN-TP) Palangka Raya.

Salah satu hasil dari bergabungnya kepercayaan Kaharingan agama resmi yaitu agama Hindu pada tahun 1980 adalah berdirinya lembaga pendidikan Hindu yaitu Pendidikan Guru Agama Hindu Parentas. PGA Parentas merupakan cikal bakal dari berdirinya Sekolah Tinggi Agama Hindu Kaharingan Tampung Penyang Palangka Raya yang kemudian beralih menjadi perguruan tinggi Hindu negeri dengan sebutan Sekolah Tinggi Agama Hindu Negeri Tampung Penyang Palangka Raya. Saat ini perguruan tinggi tersebut naik status menjadi Institut Agama Hindu Negeri Tampung Penyang Palangka Raya. Karena hilangnya kata Kaharingan ketika penegerian kampus Sekolah Tinggi Agama Hindu Kaharingan (STAHK) Tampung Penyang Palangka Raya menjadi Sekolah Tinggi Agama Hindu Negeri (STAHN) Tampung Penyang Palangka Raya, memunculkan tuduhan Kaharingan dibalikan dan ajaran Kaharingan tidak diajarkan. Hal ini muncul dari orang-orang yang tidak senang dengan adanya integrasi Kaharingan dengan agama Hindu. Namun, ditengah berbagai tuduhan lembaga pendidikan keagamaan Hindu ini tetap turut serta dalam merawat dan melesatarikan ajaran Kaharingan sebagai identitas kuktural penganut Hindu dari etnis Dayak yang ada di Kalimantan Tengah.

Tulisan-tulisan tentang Kaharingan telah banyak, namun yang mengangkat tentang bagaimana peran perguruan tinggi keagamaan Hindu dalam turut serta merawat tradisi Kaharingan tersebut belum ada. Sehingga masih sangat relevan untuk dibicarakan. Permasalahan dalam tulisan ini adalah bagaimanakah peran Institut Agama Hindu Negeri Tampung Penyang Palangka Raya dalam melestarikan Kaharingan yang merupakan identitas kultural penganut Hindu di Kalimantan Tengah? 


\section{Metode}

Penelitian ini adalah jenis penelitian deskriptif kualitatif. Sebagai bahan penyusunan dilaksanakan observasi terhadap perkembangan sistem religi Dayak Ngaju (Kaharingan) yang dikenal dengan Hindu Kaharingan saat sekarang yang berhubungan dengan peran IAHN-TP Palangka Raya dalam turut serta melestarikan dan merawat ajaran leluhur Dayak di Kalimantan Tengah. Penelitian dokumen dilakukan untuk rekonstruksi data masa lampau yang dikuatkan dengan wawancara mendalam. Pendapat Spradley (1997) dan Benard (1994) digunakan sebagai pedoman dalam menetukan informan, yaitu informan harus paham terhadap tema yang diteliti. Informan ditentukan menggunakan teknik Purposive, seturut dengan pendapat Bungin (2010) tentang beberapa kriteria yang dapat dijadikan sebagai informan. Informan dalam penelitian ini adalah Basir, tokoh, pimpinan/aktivis lembaga, Akademisi, dan penganut Hindu Kaharingan di Kota Palangka Raya. Analisis data menggunakan model dan proses penelitian Siklikal Spradley. Moleong (2016) menyatakan pada model ini langkah pengumpulan data tidak dibedakan dengan proses analisis data, namun disatupadukan.

\section{Hasil dan Pembahasan}

\section{Identitas Kultural}

Mengenai identitas kultural (Liliweri, 2002) menyatakan bahwa kebudayaan memiliki ciri-ciri serta rincian karakteristik dari sekelompok orang yang memiliki batasbatas yang berbeda dengan kebudayaan orang lain. Indonesia memiliki keberagaman kultural baik budaya, bahasa, agama maupun etnis. Mengenai keberagaman masyarakat Indonesia ini menurut Geertz (dalam Ismail, 1999) yaitu: "terdapat lebih dari 300 kelompok etnis di Indonesia, masing-masing mempunya identitas kultural sendiri-sendiri dan lebih dari 250 jenis bahasa dipakai hampir semua agama di dunia diwakili selain agama asli yang banyak sekali”.

Keberagaman kultural ini juga berlaku pada pemeluk agama Hindu di Indonesia. Sebagai salah satu agama resmi di Indonesia, Hindu tampak memiliki ciri khas praktek keberagamaan yang beragam. Berbeda dengan agama resmi lain yang lebih menunjukkan satu ragam rupa. Terjadinya keberagaman ini karena faktor ajaran. Klostermaier (1994: 1); Halbfass, (1991: 1 - 22) dalam (Segara, 2017), menulis sebagai berikut.

"Mahkamah Agung India menyatakan tidak seperti agama lainnya di dunia, agama Hindu tidak mengklaim satu nabi saja, tidak memuja satu dewa saja, tidak menganut satu konsep filosofis saja, tidak mengikuti atau mengadakan satu ritus keagamaan saja; faktanya ciri-ciri agama Hindu itu tidak seperti agama atau kepercayaan lain pada umumnya. Tak lain dan tak bukan, agama Hindu itu merupakan suatu jalan hidup".

Selain itu, keberagaman Hindu juga terjadi karena agama Hindu di Indonesia merupakan salah satu agama resmi yang menjadi tempat berlindungnya agama-agama asli nusantara seperti Kaharingan, Aluk to Dolo, Parmalim, Sunda Wiwitan, Naurus, Tengger dan lainnya yang memilih untuk menyatakan diri sebagai penganut agama Hindu karena adanya aturan negara tentang kewajiban pengisian agama pada KTP.

Selain tampak dalam praktek beragama yang beragam, keberagaman Hindu juga muncul pada identitas kultural dalam bentuk identitas etnik, sehingga memunculkan beragam sebutan seperti Hindu Kaharingan, Hindu India, Hindu Bali, Hindu Aluk to Dolo, Hindu Parmalim, Sunda Wiwitan, Naurus, Tengger dan lainnya. Menurut (Adi, dkk, 2021) secara "de jure" penyebutan identitas kehinduan yang merujuk identitas etnik seperti yang terjadi di lapangan tidak dijumpai, tetapi secara "de fakto" sudah menjadi semacam kesepakatan secara umum oleh intelektual dan umat Hindu. Sehingga di dalam kehidupan keseharian umat Hindu di Indonesia dapat dijumpai penyebutan identitas agama Hindu sesuai etnis tertentu. 
Keberagaman Hindu, termasuk dalam bentuk penyebutan identitas etnik tampak memperlihatkan Hindu sebagai agama dengan ragam wajah, bukan berwajah tunggal. Selain itu juga, hal tersebut berpotensi memunculkan konflik jika salah kelola. Karena masing-masing penganut Hindu tersebut memiliki identitas kulturalnya masing-masing. Namun di sisi yang lain, keberagaman tersebut merupakan kekayaan Hindu sebagai agama yang melindungi setiap kebudayaan dimana agama Hindu berkembang apalagi di tengah gempuran globalisasi yang serba menyeragamkan bahkan menghilangkan kebudayaan lokal. Identitas Hindu merupakan cara untuk menyatukan dan melindungi keberagaman cara beragama penganut Hindu di Indonesia termasuk penganut agama Dayak Ngaju /Helo/Kaharingan. Menjadi penganut Hindu tidak membuat penganut Hindu, termasuk yang berasal dari etnis Dayak Ngaju harus tercabut dari akarnya, bahkan mereka tetap dapat mempertahankan identitas kultural dalam praktek beragama maupun identitas jati diri secara de fakto. Hal ini sebagaimana yang dinyatakan oleh Umis I. Untung, Sika dan Pranata sebagai tokoh dan pengurus Majelis Agama Hindu Kaharingan bahwa:

Hindu dipilih berkaitan dengan makanan sudah cocok, ritual, filosofis, nilai-nilai Kaharingan sangat identik dengan agama Hindu. Asas desa, kala dan patra Hindu yang berkomitmen untuk mengeksiskan dan tidak menghilangkan ritual-ritual yang sudah dijalankan dan diyakini sehingga ajaran leluhur kami bisa terlindungi. (wawancara, 29 Januari 2020).

Identitas kultural penganut Hindu etnis Dayak Ngaju di Kota Palangka Raya yang dapat terlihat berupa praktek upacara yang dijalankan baik menyangkut siklus kehamilan, kelahiran, kehidupan dan kematian dilaksanakan sesuai ajaran Kaharingan. Lembaga keumatan, selain Parisada Hindu Dharma Indonesia (PHDI) juga terdapat Majelis Agama Hindu Kaharingan yang bertugas melayani umat Hindu dari etnis Dayak di Kalimantan Tengah dari tingkat provinsi sampai ke tingkat desa. Selain itu juga tampak pada identitas agama yang lebih dikenal dengan Hindu Kaharingan, walaupun secara administrasi hanya ditulis Hindu.

\section{Hindu Kaharingan}

Orang Dayak adalah orang yang beragama, namun menurut Hans Scharer (1963) dalam tulisannya Ngaju Religion the Conception of God Among a South Borneo People" seluruh pemikiran dan kehidupan orang Dayak mengenai agamanya harus ditafsirkan, diarahkan dan ditentukan sesuai konsepsi keilahian yang dimiliki. Lebih lanjut juga dijelaskan bahwa sebagai suatu sistem kepercayaan, suku Dayak Ngaju telah memiliki bangunan teologi yang kokoh. Mereka bukan orang yang tak mengenal tata tertib. Sistem keagamaan menyatupadu dengan sistem social kemasyarakatan dengan adanya hadat sebagai perintah dan pali sebagai larangan yang menata dan mengatur kehidupan mereka. Religi asli masyarakat Dayak Ngaju sarat dengan perangkat simbolik yang bersifat material dan nonmaterial, seperti yang terdapat dalam beragam upacara. Perangkat simbolik yang menggambarkan seperangkat persepsi dan konsepsi tentang adanya kekuatan di luar dirinya yang sangat menentukan keberadaan dan kebertahanan hidup sebagai manusia dan masyarakat.

Sebelum tahun 1950 sistem religi masyarakat Dayak disebut dengan berbagai nama seperti agama Helo, agama Ngaju, agama Tato Hiang. Kaharingan sebagai identitas sistem religi Dayak di Kalimantan Tengah mulai dikenal menjelang kemerdekaan Negara Kesatuan Republik Indonesia tahun 1945 oleh Dai Nippon (Penjajah Jepang) atas saran Yohanes Salilah sebagai salah satu tokoh Dayak yang menjabat sebagai Damang saat itu. Selain itu juga dikenalkan oleh W. A Samat dan Tjilik Riwut ketika mejabat sebagai Residen di Sampit. Kaharingan sebagai identitas agama Dayak Ngaju ini kemudian semakin diperkuat dan dideklarasikan secara resmi dalam forum yang dilaksanakan oleh 
Sarikat Kaharingan Dayak Indonesia (SKDI) pada tahun 1950. SKDI merupakan organisasi politik sekaligus sosial keagamaan yang memiliki misi untuk memperjuangkan agama Dayak Ngaju agar dapat menjadi salah satu agama resmi negara. Sugiyarto (2016) menyatakan bahwa Kaharingan sudah menjadi agama bagi suku Dayak di Kalimantan Tengah meski belum ada pembukuan ayat-ayat suci keagamaannya yang bersumber dari Tuhan (Ranying Hatala Langit). Sejak tahun 1950 umat Kaharingan dengan sekuat tenaga memperjuangkan agar sistem keyakinannya diakui. Dalam perjalanan perjuangan pengakuan yang dilakukan oleh penganut Kaharingan tidak sesukses yang dilakukan oleh penganut Hindu Bali. Sehingga kemudian terjadi integrasi kepercayaan Kaharingan dengan agama Hindu pada tahun 1980 yang memunculkan identitas Hindu Kaharingan.

Hindu Kaharingan merupakan agama Hindu yang dianut oleh penganut yang berasal dari etnis Dayak di Kalimantan Tengah yang awalnya disebut dengan Kaharingan. Namun semenjak adanya adanya integrasi kepercayaan Kaharingan dengan agama Hindu pada tahun 1980 lebih sering disebut dengan Hindu Kaharingan sebagai identitas jati diri penganutnya, sedangkan secara adminitrasi tetap tertulis Hindu. Menurut (Sugiyarto, 2016), sebelum integrasi telah dilakukan dialog antara pengurus Majelis Besar Alim Ulama Kaharingan Indonesia (MB-AUKI) bersama para tokoh Hindu di Bali yang dipimpin oleh Prof. Dr. Ida Bagus Mantra sebagai intelektual Hindu sekaligus gubernur Bali pada saat itu. Dialog mengenai teologi, ritual, dan tradisi Kaharingan memperoleh simpulan bahwa ajaran yang ada sebagai ajaran Hindu kuno yang dianut masyarakat Dayak sejak zaman Veda. Dari hasil dialog tersebut kemudian penganut Kaharingan diterima berintegrasi dengan agama Hindu. Artinya Agama Hindu dipilih setelah melewati kajian dimana hanya agama Hindu yang memiliki keluwesan dan kemiripan ajaran, baik teologis maupun upacara dengan ajaran Kaharingan sehingga dinilai dapat melindungi tradisi Kaharingan yang telah ada. Jadi ketika memilih menjadi penganut Hindu mereka tidak harus tercabut dari akar budaya yang dipertahankan.

\section{Peran IAHN-TP Palangka Raya Dalam Melestarikan Identitas Kultural Penganut Hindu Kaharingan Di Kalimantan Tengah}

Pendidikan merupakan salah satu alasan penganut sistem religi Dayak Ngaju atau Kaharingan berintegrasi agama Hindu. Sebelum berintegrasi penganut sistem religi Dayak Ngaju tidak mendapatkan haknya dalam memperoleh pendidikan agama karena pada saat itu Kaharingan hanya dianggap kepercayaan dan tidak ada guru agamanya. Namun, pascaintegrasi dengan agama Hindu secara perlahan para penganut Kaharingan dapat mengakses pendidikan agama Hindu yang juga mengakomodasi ajaran Kaharingan dalam proses pembelajarannya.

Menurut (Utama, 2016), munculnya regulasi negara dalam bidang pendidikan agama secara formal tanpa disadari telah membangun keseragaman pengetahuan agama, tetapi kurang peduli terhadap praktiknya. Sebaliknya, pendidikan agama juga harus berkaitan dengan praktik dalam pelaksanaan kehidupan sosial selain berhubungan dengan pengetahuan kognitif manusia. Secara umum diketahui bahwa pendidikan agama termasuk pendidikan agama Hindu yang didapat anak-anak di sekolah mengikuti kurikulum yang telah ditetapkan secara nasional yang lebih banyak menekankan pada aspek tattwa dan etika agama. Sehingga dalam pelaksanaan pendidikan agama menerapkan keseragaman. Namun, hal yang berbeda untuk di Provinsi Kalimantan Tengah, Sisto Hartati dan Delae bahwa:

Pola pendidikan agama Hindu yang dilakukan oleh guru dan dosen agama Hindu di Kalimantan Tengah khususnya di Kota Palangka Raya adalah dengan mengkolaborasikan ajaran Hindu secara umum dengan ajaran Kaharingan yang merupakan praktek keagamaan yang ada pada penganut Hindu Kaharingan 
terutama upacara-upacara, sarana upacara, dan ibadah berupa basarah dan teologisnya. Contohnya ketika materi panca yajna, maka akan dikolaborasikan dengan penjelasan seperti apa prakteknya dalam upacara-upacara Kaharingan (wawancara 14 Januari 2020).

Adapun untuk di Institut Agama Hindu Negeri Tampung Penyang salah satu dosen pengampu mata kuliah Tandak sekaligus Ketua Prodi Pendidikan Seni dan Keagamaan pada Fakuktas Dharma Acarya, Komang Suarta, mengatakan: "IAHN-TP Palangka Raya sebagai satu-satunya perguruan tinggi Hindu yang ada di Kalimantan menjadikan beberapa khazanah lokal sistem religi Dayak Ngaju atau Kaharingan sebagai mata kuliah. Jadi, ajaran Hindu secara umum menjadi rujukan, namun dalam penjelasannya akan mengerucut pada ajaran Kaharingan sesuai apa yang dipraktekkan di lapangan" (wawancara 19 April 2020).

Jadi pelaksanaan pendidikan keagamaan Hindu tetap berpedoman pada kurikulum yang ditetapkan oleh pemerintah secara nasional. Namun, dalam prakteknya di daerah Provinsi Kalimantan Tengah para guru dan dosen menyinergikan materi agama Hindu dengan ajaran lokal Kaharingan sebagai praktik beragama peserta didik. Hal ini seturut dengan pendapat (Utama, 2016) yang menyatakan bahwa sebaiknya pendidikan agama Hindu di Indonesia selain berpedoman pada kurikulum yang diterapkan pemerintah, guru harus mampu menyinergikannya dengan hal-hal yang bersifat lokalitas (kedaerahan) sehingga pendidikan agama Hindu lebih nyambung dan sesuai dengan kebutuhan dan kondisi nyata masyarakat tingkat lokal. Hal ini perlu dilakukan, agar pendidikan agama tidak hanya sekadar menjadi proses transformasi pengetahuan keagamaan semata. Sebagaimana pendapat (Suda, 2017) yang menyatakan bahwa misi masuknya pendidikan agama Hindu pada kurikulum pendidikan formal adalah untuk peningkatan sradha dan bhakti serta justifikasi iman sisya (siswa) agar dapat mengedepankan dan menerapkan nilai moral dan agama secara nyata dalam kehidupan sehari-hari di masyarakat.

IAHN-TP Palangka Raya merupakan transformasi dari STAHN Tampung Penyang Palangka Raya melalui Perpres Nomor 31, Tahun 2018 tanggal 5 April 2018 memiliki visi dan misi yang diwujudkan melalui kegiatan tri dharma perguruan tinggi. Visi yang ingin dicapai adalah "unggul, profesional, dan religius" sedangkan misinya adalah (1) Menghasilkan lulusan unggulan, (2) Menghasilkan penelitian berkualitas, (3) Mewujudkan pengabdian kepada masyarakat religius yang inovatif, dan (4) Membangun kerja sama, sarana prasarana yang berbasis IPTEK.

Keberadaan IAHN Tampung Penyang Palangka Raya sekarang merupakan nyata dari upaya yang telah dilakukan Majelis Besar Agama Hindu Kaharingan (MB-AHK) Pusat Palangka Raya, PHDI Provinsi Kalimantan Tengah, Pembimbing Masyarakat Hindu dan Budha Kantor Wilayah Departemen Agama Kalimantan Tengah beserta tokoh-tokoh yang berjasa dalam merintis pendirian PGAHK Parentas. Tokoh-tokoh seperti Lewis K.D.R., B.BA, Drs. Oka Swastika, S.H, I.D.M Greh Putra, Simal Penyang, Bajik R. Simpei, Drs. Liber Sigai, I Wayan Madu, Drs. Kundit U. Djunas, Drs. Walter S. Penyang Drs. Arton S. Dohong dan lainnya. Sekolah keagamaan Hindu ini didirikan dalam rangka menyiapkan sumber daya manusia di bidang pendidikan, penyuluh, ahli agama, dan memenuhi tenaga pendidik di semua jenjang pendidikan di Kalimantan Tengah.

IAHN-TP Palangka Raya sebagai kampus Hindu satu-satunya di Kalimantan memiliki peran besar dalam pengembangan dan pelestarian ajaran Kaharingan. Tidak hanya ajaran Kaharingan yang bersumber dari agama Dayak Ngaju, tetapi juga dari Dayak lainnya, seperti Dayak Luangan, Dayak Siang, Dayak Murung, Dayak Maanyan, Dayak Tumon (Lamandau), Dayak Ruku Mapam (Sukamara), dan lainnya yang ada di Kalimantan Tengah bahkan tradisi religi yang ada pada Dayak Meratus Kalimantan 
Selatan. Hal ini dilakukan karena mahasiswa IAHN-TP Palangka Raya juga berasal dari luar Kalimantan Tengah.

Ditengah berbagai isu yang sering muncul terhadap keberadaan kampus IAHN-TP Palangka Raya sebagai kampus keagamaan Hindu yang tidak mengajarkan kearipan Kaharingan, berbagai upaya dilakukan untuk menjawab semua tuduhan tersebut dengan tindakan nyata dalam merawat, mengembangkan dan melestarikan ajaran Kaharingan. Salah satu adalah menjadikannya ajaran Kaharingan sebagai mata kuliah wajib dan penciri pada beberapa program studi yang ada. Ajaran Kaharingan menjadi kurikulum wajib sejak kampus ini berstatus kampus negeri yaitu Sekolah Tinggi Agama Hindu Negeri Tampung Penyang (STAHN-TP) Palangka Raya. Terdapat beberapa mata kuliah yang berkaitan dengan tradisi religi Dayak sebagaimana dijelaskan oleh Wakil Rektor I Bidang Pendidikan pada Institut Agama Hindu Negeri Tampung Penyang Palangka Raya, yaitu bapak Pranata berikut.

Semenjak kampus Sekolah Tinggi Agama Hindu Kaharingan Tampung Penyang (STAHK-TP) Palangka Raya dinegerikan pada tahun 2001 menjadi Sekolah Tinggi Agama Hindu Negeri Tampung Penyang (STAH-TP) Palangka Raya terdapat beberapa mata kuliah yang bersumber dari ajaran Kaharingan masuk dalam kurikulum wajib seperti mata kuliah Tawur, Panaturan, Acara Agama Hindu Kaharingan, Tandak, Bahasa Daerah, Teologi Hindu Kaharingan, bahasa Sangiang. Hal ini dilakukan sebagai upaya turut serta menjaga keberadaan ajaran Kaharingan tetap lestari dan dapat diwariskan terus-menerus kepada para generasi selanjutnya (wawancara 29 Januari 2020)

IAHN-TP Palangka Raya mengakomodasi kepentingan keberlangsungan pengembangan identitas dan ajaran sistem religi Dayak Ngaju atau Kaharingan. Walaupun ketika alih status dari kampus swasta STAHK Tampung Penyang Palangka Raya menjadi negeri STAHN Tampung Penyang Palang Raya, kata Kaharingan pada nama kampus harus hilang disesuaikan dengan ketentuan negara. Namun, ajaran Kaharingan tidak dihilangkan justru semakin banyak diakomodasi pada kegiatan tri dharma peguruan tinggi di kampus tersebut, seperti menjadi mata kuliah, tema penelitian, dan pengabdian.

Pada kurikulum pendidikannya IAHN-TP Palangka Raya menerapkan kurikulum berwawasan global yang diterapkan melalui mata kuliah umum, mata kuliah inti keilmuan, mata kuliah penunjang keilmuan dan mata kuliah penciri. Sedangkan ajaran local wisdom kearipan Kaharingan terdapat pada mata kuliah inti keilmuan, penunjang keilmuan, penciri dan mata kuliah pilihan. Hal ini dapat terlihat pada data kurikulum dan sebaran mata kuliah KKNI Prodi Pendidikan Seni dan Keagamaan yang diambil sebagai salah satu sampel di bawah ini.

Tabel 1. Struktur Kurikulum \& Sebaran Mata Kuliah KKNI Program Studi Pendidikan Seni dan Keagamaan

\begin{tabular}{|c|c|c|c|c|}
\hline NO & KODE & MATA KULIAH & SKS & SEMESTER \\
\hline A & & MATA KULIAH UMUM & & $\begin{array}{llllllll}1 & 2 & 3 & 4 & 5 & 6 & 7 & 8 \\
\end{array}$ \\
\hline 1 & A 1 & Pendidikan Agama & 2 & 2 \\
\hline 2 & A 2 & Pendidikan Pancasila & 2 & 2 \\
\hline 3 & A 3 & Pendidikan Kewarganegaraan & 2 & 2 \\
\hline 4 & A 4 & Bahasa Indonesia & 2 & 2 \\
\hline & & JUMLAH & 8 & \\
\hline $\mathrm{B}$ & & MATA KULIAH INTI KEIL & AN & \\
\hline 1 & B 1 & Psikologi Pendidikan & 2 & 2 \\
\hline 2 & B 2 & Filsafat Pendidikan & 2 & 2 \\
\hline
\end{tabular}




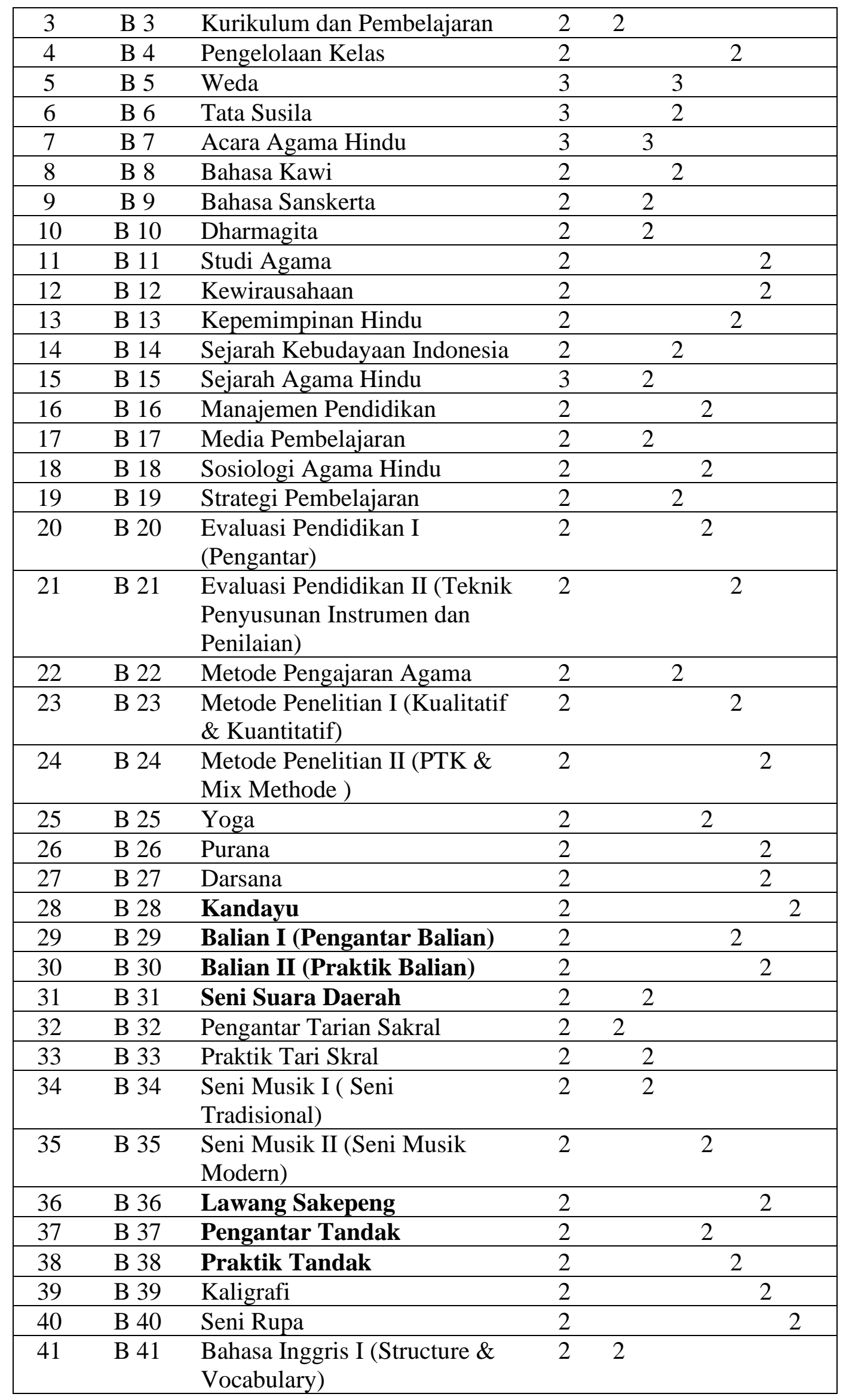






Sumber: Kaprodi Pendidikan Seni dan Keagamaan IAHN-TP Palangka Raya 
Selain dalam bentuk mata kuliah, kegiatan pengabdian dan penelitian ajaran Kaharingan juga menjadi ciri khas kampus IAHN-TP Palangka Raya, baik dalam bentuk bangunan pemujaan, seperti keramat, balai antang, dan rumah ibadah berupa balai basarah. Pelatihan-pelatihan upacara berbasis kearipan Kaharingan, seperti upacara perkawinan, balian, pandudusan dan lainnya termasuk pelatihan membuat sarana upakara menjadi program kegiatan wajib setiap tahunnya. Aktivitas persembahyangan di kampus IAHN-TP Palangka Raya adalah basarah. Namun, ketika ada hari raya keagamaan Hindu secara umum mahasiswa juga turut bersembahyang di pura. Di balai kampus juga diadakan persembahyangan yang berkaitan dengan hari suci agama Hindu, seperti Saraswati, Siwaratri, Galungan, dan Kuningan. Mantram gayatri dilantunkan dalam nada tandak yang merupakan ciri khas Kaharingan".

IAHN-TP Palangka Raya juga telah menerbitkan beberapa buku yang merupakan hasil penelitian terhadap ajaran Hindu Kaharingan. Pada tahun 2006 Pranata dkk., misalnya, menulis buku yang berjudul Upacara Ritual Perkawinan Agama Hindu Kaharingan (dalam Kitab Suci Panaturan) Filosofi Perkawinan Nyai Endas Bulau Lisan Tingang dengan Raja Garing Hatungku. Pada tahun 2016 dicetak buku Upacara Keagamaan Hindu Kaharingan, Ketuhanan dalam Ajaran Hindu Kaharingan, Tawur dalam Agama Hindu Kaharingan, Tandak dan Penuturan Simbolik Konsep Panca Sradha dalam Kitab Suci Panaturan.

Keberadaan IAHN-TP ini menyebabkan jangkauan pembinaan terhadap umat Hindu juga dapat dilakukan sampai ke pelosok daerah Kalimantan Tengah, bahkan sampai lintas Provinsi Kalimantan. Hal itu terjadi karena dukungan anggaran dan kegiatan tri dharma perguruan tinggi dosen dan mahasiswa di kampus tersebut. Dalam hal ini mustahil jika hanya bergantung pada lembaga agama yang ada karena keterbatasan dana dan sumber daya manusia. Melalui keberadaan IAHN-TP ini juga ajaran-ajaran Kaharingan dapat terus diwariskan dengan berbagai program yang dijalankan, seperti praktik acara agama dan pelatihan acara agama.

Penelitian ini menemukan bahwa IAHN-TP Palangka Raya menerapkan pola pendidikan berwawasan global untuk menjawab kebutuhan tuntutan globalisasi dan pendidikan Hindu berbasis local wisdom Kaharingan sebagai jati diri atau identitas kultural. Sehingga sumber daya manusia Hindu mampu menghadapi kompetensi global namun tetap tidak tercabut dari akar budayanya. Melalui penerapan pola pendidikan global dan pendidikan Hindu berbasis kearipan lokal secara bersama, maka akan dapat memperkuat local wisdom sebagai identitas dan jati diri. Pada kondisi ini terlihat bahwa ketika aspek lokalitas mau beradaptasi dalam bentuk sikap akomodatif dengan globalisasi, maka globalisasi mampu menghidupkan bahkan melestarikan aspek lokalitas tersebut agar tetap eksis. Akomodatif menurut (Trijono, 2004), dapat terjadi selama etnik lokal dan kelompok agama menerima globalisasi dan masuk ke dinamika global praktik kebudayaan dan sistem ekonomi dari kapitalisme. Akan tetapi, hanya untuk menguatkan dan menghidupkan kembali kebudayaan dan identitas mereka. Jika dikaitkan dengan peran IAHN-TP Palangka Raya dalam melestarikan identitas kultural penganut Hindu Kaharingan Di Kalimantan Tengah tampak bahwa IAHN-TP Palangka Raya selain mencetak SDM Hindu yang mampu menjawab tantangan global juga mengangkat local wisdom Kaharingan sebagai identitas kuktural peserta didik, sehingga ajaran Kaharingan tetap mampu bertahan bahkan lestari. Sehingga tujuan dari pendidikan, khususnya pendidikan agama nyambung dan sesuai dengan kebutuhan dan kondisi nyata masyarakat tingkat lokal sebagai pengguna lulusan. 


\section{Kesimpulan}

Keberadaan IAHN-TP Palangka Raya turut menjadi pendukung dalam pemeliharaan, pelestarian, dan penyebaran ajaran Hindu Kaharingan. Pada awalnya ajaran Kaharingan hanya dijalankan dan diwariskan secara turun-temurun melalui tradisi lisan. Akan tetapi, dengan keberadaan IAHN-TP ini mampu membuatnya menjadi tradisi tulis. Setelah terjadi integrasi dengan agama Hindu mereka mendapatkan masa depan yang lebih baik. Banyak ajaran Kaharingan menjadi mata kuliah bahkan kegiatan praktek yang menjadi program kerja tahunan di perguruan tinggi Hindu, yaitu IAHN-TP Palangka Raya yang tidak ditemukan pada perguruan tinggi Hindu lainnya. Penerapan pendidikan berbasis local wisdom ini dapat terlihat bentuk mata kuliah kearipan lokal seperti mata kuliah Tawur, Tandak, Acara Agama Hindu Kaharingan, Panaturan, bahasa Sangiang, bahasa Daerah, Teologi Hindu Kaharingan, dan mata kuliah kearipan Kaharingan lainnya. Perguruan tinggi memiliki peran dan tanggungjawab untuk menjaga local wisdom sebagai jati diri sebuah komunitas. Sehingga sumber daya manusia Hindu selain memiliki daya saing menghadapi tantangan globalisasi namun juga tidak tercabut dari akar budayanya.

\section{Daftar Pustaka}

Adi, A., Sudarsana, I. M., \& Kusuma, I. R. W. (2021, April). Varian Identitas Hindu di Indonesia: Antara Multikulturalisme dan Bhinnêka Tunggal İka. In Prosiding Seminar Nasional Institut Agama Hindu Negeri Tampung Penyang Palangka Raya (No. 2, pp. 32-42).

Alo, Liliweri. (2002). Makna Budaya dalam Komunikasi antar Budaya.Yogyakarta: PT. LKiS Pelangi Aksara

Anonim. (2017). Dokumen Integrasi Umat Kaharingan dengan Hindu Tahun 1980 dan Lain-lain. Palangka Raya: Kantor Wilayah Departemen Agama Provinsi Kalimantan Tengah

Benard, Russell, H. (1994). Research Method in Anthrpology. London-New Delhi: SAGE Publication.

Bungin, Burhan. (2010). Analisis Data Penelitian Kualitatif, Pemahaman Filosofis dan Metodologis ke Arah Penguasaan Model Aplikasi. Jakarta: Raja Grafindo Persada.

Geerttz, Clifford. (1992). Tafsir Kebudayaan. Jakarta: Kanisius.

Ismail, Faisal. (1999. Ideologi Hegemoni dan otoritas Agama Wacana Ketegangan Kreatif Islam dan Pancasila. Yogyakarta: Tiara Wacana

Moleong, Lexy J. 2016. Metodologi Penelitian Kualitatif. Bandung: Remaja Rosdakarya.

Scarer, Hans. (2016). Ngaju Religion the Conception of God Among A South Borneo People. The Hague: Martinus Nijhoff. Diterjemahkan oleh Marko Mahin. Palangka Raya: Dewan Adat Dayak Provinsi Kalimantan Tengah.

Segara, I Nyoman. (2017). Dimensi Tradisional dan Spiritual Agama Hindu. di: Rosidi, Achmad., Asnawati., Kustini., Ulum, Raudatul., Nuhrison M. Nuh., Reslawati., Suhanah., Ubaidillah., Sugiyarto, Wahid., Eko, Zainal. Editor: Segara, I Nyoman. Jakarta: Puslitbang Bimas Agama dan Layanan Keagamaan Badan Litbang dan Diklat Kementerian Agama RI. Hal. 3.

Spadley, James P. (1997). Metode Etnografi. Diterjemahkan oleh Misbah Zulfa Elizabeth. Yogyakarta: Tiara Wacana Yogya.

Suda, I Ketut. (2017). Kastanisasi Pendidikan Ketika Pelajaran Agama Terpinggirkan. Denpasar: Program Pascasarjana Universitas Hindu Indonesia.

Sugiyarto, Wakhid. (2016). "Eksistensi Agama Hindu Kaharingan di Kota Palangka Raya Kalimantan Tengah". Jurnal Harmoni. Vol 15

Utama, Budi. (2016). Wajah Bali Tanpa Kasta: Pudarnya identitas Bali Aga. Denpasar: Pustaka Ekspresi. 